\title{
For he on honeydew hath fed...
}

\author{
...and drunk the milk of Paradise.
}

\section{PaulSmaglik}

A big, bloated castle on the horizon, bleeding into the setting sun. Hearst Manor. San Simeon.

"I wish we had time to go," I said. In Xanadu did Kubla Kane...

"Oh, Alfred," she said. "You're obsessed.

"I can't help it."

"I know, I know. The same birthdays. The same professions. Except you're not a multi-billionaire. You don't control a vast media empire. You don't start wars to sell more newspapers. Brilliant young filmmakers don't create groundbreaking cinema based on your life. And you don't have sordid affairs that threaten your political aspirations. ..."

"Rosebud," I said, kissing her on the nose.

"You'd better not, anyway," she said. "And don't forget to watch the road."

In fact, I could hardly take myeyes off it. The castle was an eye-magnet. More Transylvania than California. More Dracula than Disneyland. Although it did have that Anaheim aesthetic, plunked down in the middle of the Big Sur. The landscape of America. The landscape of nowhere. A history of architecture in one building. NeoGothic PostColonial Revisionism. The art nouveau of wretched excess. Pediments and gables. Towers and balconies. Dormers, cornices, columns. Spires and gargoyles. Things that go bump in the night. The world's biggest and most expensive crypt improbably placed far from graveyards or amusement parks.

Vampire Kane.

"What if he's still alive?" I asked.

"You're crazy."

"No, really - what if he's not allowed to die, or refused to go gently into that good night, as they say, until he's seen everything he's collected, played with all his toys, read all the books, seen all the films, tried on every single suit, laced up and slipped on every pair of shoes?"

She sighed and shook her head.

"It's quite possible," I insisted. "The miracles of modern medicine and all."

She looked away suddenly and stared intently out of the window.

The wrong thing to say after reproductive technology recently let us down. But it was true, theoretically. Cellular immortality, thanks to telomerase. Keeps the DNA from getting frayed, like the ends of an old rope. So the cells can divide over and over and over again, with no defects. A genetic photocopier with amazing resolution.

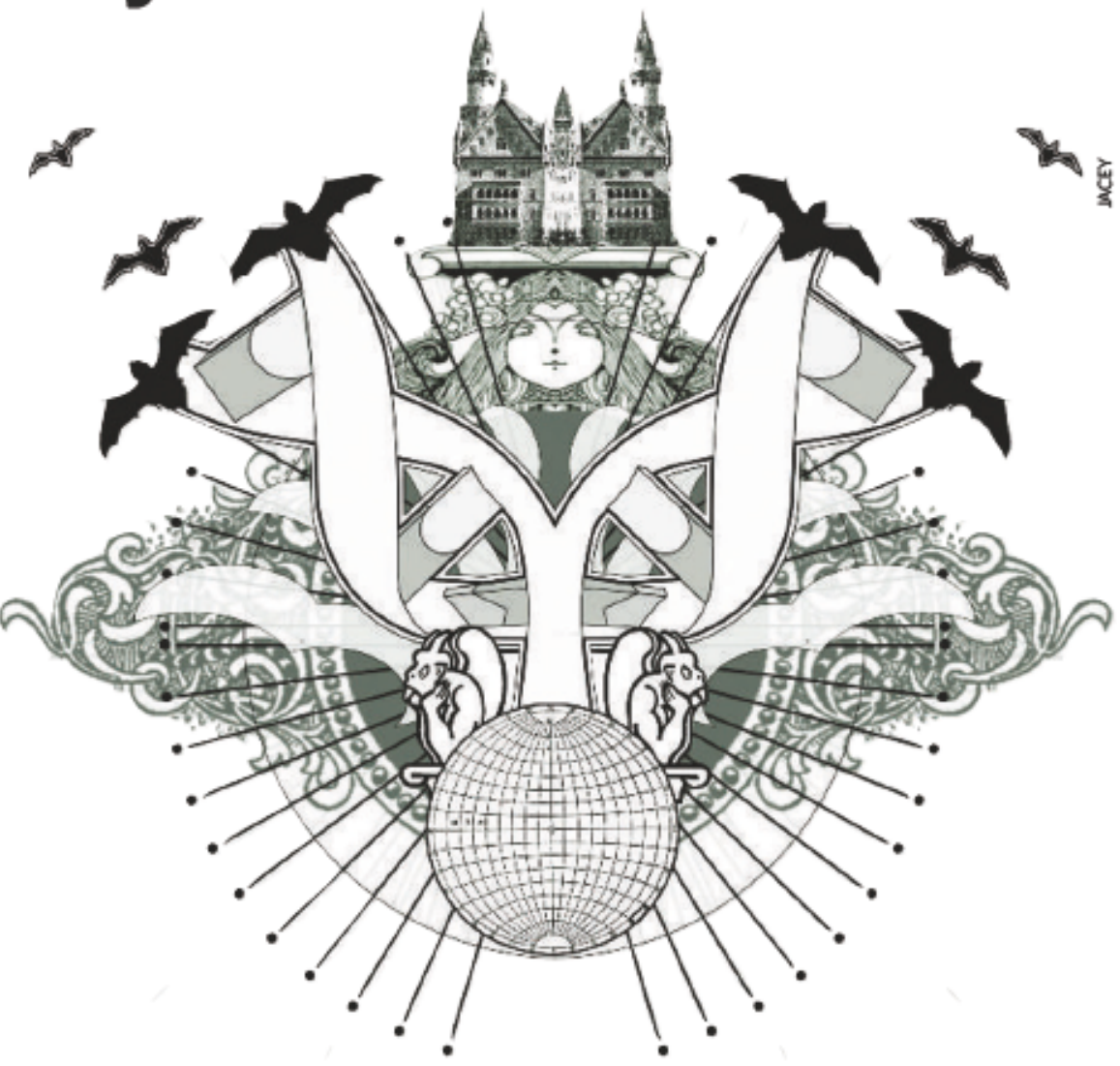

Not yet available at a hospital near you. Not yet. But they already sell spare parts now, hearts and lungs, kidneys and livers, grown up from embryos, fetal tissue, skin scraped off the tip of your own nose. They have waiting lists, but it's amazing what a little cash can do. Bump you up to the front of the line. Strictly hush-hush money, of course. Especially if you're already supposed to be dead, not just going through desperate measures to fend it off due to vanity and insecurity. Although that probably has something to do with it. Along with the ability to do it.

Why climb Mount Everest? Because it is there.

Why live forever? Because you can.

A tune-up every 100,000 miles or every ten years, whatever comes first. The money's in the bank, the cheque's in the post. Synthetic joints, artificial cheek bones, stainless-steel supports, rack-andpinion steering. Gives 'a new lease of life' a whole new meaning.

Just call in the docs whenever necessary and nip and cut and bait and switch and presto! A whole new circulatory system! Nanotube technology, brimming with synthetic blood. Or maybe a new skin. After a few months of healing (what are a few months when you've got forever?) unwrap the gauze and remove the iv. drip and take a look around the pharaoh's tomb, somewhere deep within the bowels.
Then throw the bandages aside and start taking stock.

I can picture him, appearing from some nook after the last tourist has left, slipping the guard a Benjamin from his unlimited supply. He'd have to read the newspaper first. A Hearst publication, of course. Then the competition's. Then all his press clippings of the day. Everything germane to the company. Which is pretty much everything. But that's the way it goes when you've got a multinational, horizontal conglomerate. Everything connects to everything else, somehow. Everything is relevant.

By the time he has processed all the day's news, he will sense the sun rising, take a quick peek at some crated work of art, some great hidden Picasso, maybe, sigh, then disappear for the day. He'd never be done. He'd barely ever even get started. Maybe he still controls his empire. By proxy. By secret decree. Maybe there's a series of Venn diagrams in a safe somewhere covering every possible decision. Or flow charts. Marching orders. Battle plans. It can't be that hard, anyway. Buy. Build. Expand. Conquer. People do it every day. They have their names on buildings to prove it.

Paul Smaglik edits the Naturejobs and from an as-yet-unpublished novel with the working title of Monument. Authors sections of Nature. This excerpt is 